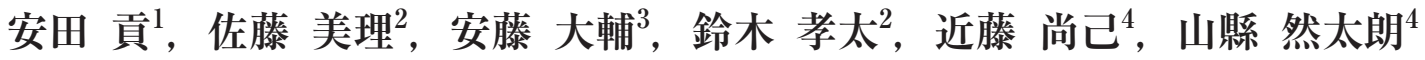

\section{The association between physical activity and depressive symptoms among japanese school children}

\author{
Mitsugu Yasuda ${ }^{1}$, Miri Sato ${ }^{2}$, Daisuke Ando ${ }^{3}$, Kohta Suzuki ${ }^{2}$, Naoki Kondo ${ }^{4}$ and Zentaro Yamagata ${ }^{4}$ \\ ${ }^{1}$ 札幌大学経営学部， $=062-8520$ 北海道札幌市豊平区西岡3条7丁目3-1 (Department of Business Administration, \\ Sapporo University, 3-7, Nishioka, Toyohira-ku, Sapporo, Hokkaido 062-8520, Japan) \\ 2 山梨大学大学院医学工学総合研究部附属出生コホート研究センター, ₹409-3898 山梨県中央市下河東1110 (Center \\ for Birth Cohort Studies, Interdisciplinary Graduate School of Medicine and Engineering, University of Yamanashi, \\ 1110 Shimokato, Chuo, Yamanashi 409-3898, Japan) \\ ${ }^{3}$ 防衛大学校体育学教育室, =239-8686 神奈川県横須賀市走水1-10-20 (Department of Physical Education, National \\ Defence Academy, 1-10-20 Hashirimizu, Yokosuka, Kanagawa 239-8686, Japan) \\ ${ }^{4}$ 山梨大学大学院医学工学総合研究部社会医学講座， ₹409-3898 山梨県中央市下河東1110 (Department of Health \\ Sciences, Interdisciplinary Graduate School of Medicine and Engineering, University of Yamanashi, 1110 Shimokato, \\ Chuo, Yamanashi 409-3898, Japan)
}

Received: September 1, 2011 / Accepted: March 21, 2012

\begin{abstract}
In recent years, physical inactivity among children or adolescents has been a major public health concern. Although a number of studies have examined the effect of physical inactivity on depressive symptoms in adults, only few studies have examined this effect on children. Therefore, the purpose of this study was to examine the effect of physical activity on the development of depressive symptoms in children by using longitudinal data. The study participants were students in grades 4 to 8 in the Koshu City. Their physical activity and depressive symptoms were examined in 2008 by a questionnaire. One year later, their depressive symptoms were examined again. Students who had depressive symptoms at the baseline were excluded. Physical activity at the baseline was categorized into 3 groups as independent variables. The development of depressive symptoms was used as the dependent variable. Multivariate logistic regression analyses were performed to examine the relationship. At the baseline, 1532 students completed the questionnaire. Of them, 1379 students ( 727 boys and 652 girls) did not have depressive symptoms. One year later, 1319 students (95.6\%) completed the questionnaires on depressive symptoms. Of them, $41(6.0 \%)$ boys and 68 (10.6\%) girls had developed depressive symptoms during the study period. High physical activity was significantly associated with decreased incidence of depressive symptoms compared to low physical activity only in boys (odds ratio: $0.37,95 \%$ confidence interval: $0.12-0.95$ ). Our results suggest that high physical activity significantly affects the depressive symptoms in boys.
\end{abstract}

Jpn J Phys Fitness Sports Med, 61(3): 343-350 (2012)

Keywords : Children, Physical activity, Depressive symptoms, Prospective cohort study

\section{緒言}

近年，小児に打ける身体活動量の低下が公衆衛生上の 問題となっている。身体活動の重要性は認識されている ものの, 生活作業の機械化・自動化やポータブルゲーム 機の普及等により小児の 1 日あたりの歩数が減少してい ることが示されている11. 小児の低い身体活動レベルは, 肥満 ${ }^{2)}$, 糖尿病 ${ }^{3)}$, 心血管疾患 ${ }^{4)}$ など身体的リスクになる ことが知られている。ささらに，身体活動量の低下は身体
的リスクだけではなく, メンタルヘルスにも影響を及ぼ すことも明らかとなっている5 .

身体活動とメンタルヘルスの関連において，成人では 縦断的な検討が数多く行なわれている。例えば，身体活 動の強度に関わらず 1 週間あたり 20～60分程度の身体活 動を行なうことが，抑うつ症状を低下させることが明ら かとなっている6-8)．しかしながら，小児の身体活動が メンタルヘルスに及ぼす影響のエビデンスは，わずか に報告されている縦断研究 9 や横断研究10) に基づいてお 
り，エビデンスの不足から因果関係を明らかにするまで には至っていない.

我が国の小児においても，うつ病が存在していること が報告されており, その有病率は 12 歳未満の児童期で 0.5 〜 2.5\%，12歳から 17歳の青年期で2.0〜 8.0\%に及ぶこと が示されている11)。小児のうつ病は, 適切な治療が行な われなければ, 成人になって再発したり, 他の様々な障 害を合併したり，対人関係や社会生活における障害が持 ち越されてしまう場合が少なくない11)。近年, 子どもの うつ病が一般的に認識されているよりもずっと多く存在 しており ${ }^{11)}$ ，小児のうつ病が増加していると考えられる こと，そして小児の身体活動量が低水準である中で，成 人において身体活動とメンタルヘルスの関連が指摘され ている点を考慮すると, 小児での身体活動の低さは抑う つの発症に関連すると考えられる。ささらに小児が抑うつ を発症する原因として生活習慣の悪さ ${ }^{12,13)}$, 過体重 ${ }^{14)}$, ボデイイメージの歪み ${ }^{15)}$ ，社会経済状況が低い16)，親が 抑うつ症状を有している17)などが報告されている。生活 習慣 ${ }^{18)}, \mathrm{BMI}^{19)}$ ， ボディイメージ20) は身体活動にも影響 を及ぼすことから，身体活動と抑うつの発症の関係に影 響を与える交絡因子であることが考えられる。

そこで本研究は，これらの交絡因子を調査した上で, 小児を対象に身体活動が抑うつの発症に及ぼす影響を縦 断研究から明らかにすることを目的とした。

\section{対象および方法}

調査対象 調査対象は2008年に山梨県甲州市の小学校 4 年生から中学校 2 年生までの18小中学校に在籍していた 児童生徒である。

調査期間および内容上記対象者に対して，「児童生徒 の心の健康と生活習慣に関する調査」を, 2008年 6〜 7 月に各学校において行なった。調査は表紙に説明書きを 施した調査票を配布し, 担任教諭が口頭による説明を行 ない, 同意を取った。そしてクラス単位で, 児童生徒に 無記名で調査票記入を依頼して, 回答後各自厳封の上, 回収した。さらに2009年 $6 \sim 7$ 月にも同様の調査を行
なった。また，それぞれの調査実施時に児童生徒健康診 断票より，対象児の調査年度の身長および体重データを 抽出することも調査時に担任教諭が説明し, 同意を取っ た。本調査では, 児童生徒の心の健康を表す指標として 抑うつ症状を採択した。スクリーニングには18項目か らなるBirleson depressive self-rating scale for children $(\mathrm{DSRS}-\mathrm{C})^{21)}$ を日本で標準化した尺度 ${ }^{22)}$ を用いた。合計 得点の範囲は 0 ～36点である。本研究ではベースライン で抑うつ症状を有していた児童生徒は解析から除外し, 1 年後のDSRS $-C$ 得点が16点以上であった児童生徒は新 たに抑うつ症状を呈すると定義した。なお，この評価尺 度において，新たに抑うつ症状を呈すると判断された览 童生徒のうち，うつ病と判断できるものは20～30\%であ ることが報告されている ${ }^{23)}$ 。生活習慣および体型につい ては身体活動時間，朝食摂取状況，平日の就寝時刻，朝 の目覚め感，テレビゲーム等の利用時間，ボデイイメー ジを調査した。身体活動に関する調查は，信頼性およ び併存的妥当性が示されている高倉らの報告 ${ }^{24)}$ を参考に “あなたはふだん，体育の時間以外で週に合計何時間く らい，体を動かしていますか（例えば，部活動，スポー ツ少年団，スイミングやテニススクールなど)”という質 問に対して,「1。週に合計して,約（）時間 2。 まっ たくしない」で評定した。 その他の調査項目および評定 は付表にまとめた。 Body mass index (BMI) は，身長 および体重で算出 (体重 $(\mathrm{kg}) \div$ 身長 $\left.(\mathrm{m})^{2}\right)$ され, 性・年 齢を考慮した国際基準 ${ }^{25,26)}$ にあるBMIのカットオフ值を 用いて「やせ」「標準」「過体重」に分類した。

解析方法 統計解析は全て男女別に行なった。就寝時刻 は中央值で 2 群に分け，小学生が22時以降，中学生が23 時以降を就寝時刻の遅い群とした。1 週間あたり体育の 時間以外で体を動かしている時間（以下, 身体活動時間） は男女別，学年別に 3 分位に分類した（Table 1)。ベー スラインの身体活動時間を短時間群，中時間群，長時間 群の 3 群として独立変数とした。身体活動時間と従属変 数である新たに抑うつ症状を呈する览童生徒との関係は オッズ比 (odds ratio, 以下OR) および95\%信頼区間 (95\%

Table 1. Baseline characteristics by tertile of physical activity hour by gender and grade

\begin{tabular}{cccccccc} 
& \multicolumn{3}{c}{ Boys } & & \multicolumn{3}{c}{ Girls } \\
\cline { 2 - 4 } \cline { 6 - 8 } School Grade & Low & Middle & High & & Low & Middle & High \\
\hline 4 & $0 \sim 2$ & $3 \sim 6$ & $7 \sim$ & & $0 \sim 1$ & $2 \sim 3$ & $4 \sim$ \\
5 & $0 \sim 4$ & $5 \sim 10$ & $11 \sim$ & & $0 \sim 2$ & $3 \sim 5$ & $6 \sim$ \\
6 & $0 \sim 5$ & $6 \sim 12$ & $13 \sim$ & & $0 \sim 2$ & $3 \sim 7$ & $8 \sim$ \\
7 & $0 \sim 9$ & $10 \sim 17$ & $18 \sim$ & & $0 \sim 6$ & $7 \sim 15$ & $16 \sim$ \\
8 & $0 \sim 12$ & $13 \sim 18$ & $19 \sim$ & & $0 \sim 6$ & $7 \sim 14$ & $15 \sim$ \\
\hline
\end{tabular}


confidence interval, 以下 $95 \%$ CI）を求めるためにロジ スティック回帰分析を用いて行なわれた。なお，生活習 慣，BMI，ボデイイメージは調整変数とした。解析には SAS Institute Inc製 JMP8を用いた。

本研究の実施にあたっては, 山梨大学医学部倫理委員 会の承認を得ている。公表に㧈いては個人が特定できな いように配慮を行なった。

\section{結 果}

解析対象の児童生徒 本研究の解析対象は, 2008年に山 梨県甲州市の小学校 4 年生から中学校 2 年生までの 18 小 中学校に在籍していた児童生徒1690人（男子879人，女 子811人）のうちベースライン（2008年の調査時）で, DSRS-C尺度に記入漏机があり抑うつ症状の判定が不可 能であった $129 人 ，$ 抑うつ症状を有していた 153 人，身体 活動時間が未記入または 1 週間あたり150時間以上を記 入していた 29 人を除外し，さらに 1 年後にDSRS-C尺度 に記入漏れがあり抑うつ症状の判定が不可能であった60 人を除いた児童生徒1319人（男子 678 人，女子 641 人）で ある，追跡率は $95.6 \%$ あった。

ベースラインのDSRS-C得点 男女別, 学年別に新た に抑うつ症状を呈さなかった群と呈した群のベースライ ン時（2008年）に扔ける抑うつ評価尺度得点を比較し た（Table 2). 新たに抑うつ症状を呈した群が少人数で あったことから，群間の比較にはウィルコクスンの順位
和検定を用いて解析を行なった。男子は，中学 1 年生お よび 2 年生で有意差が認められた。 女子は, 小学 5 年 生以外で有意差が認められた。そのため多変量ロジス テイック回帰分析ではベースラインのDSRS-C得点で調 整を行なった。

ベースラインの身体活動時間 男女別，学年別に 1 週間 あたりの身体活動時間の平均值および標準偏差を示した (Table 3). 全ての学年で男子の方が女子よりも身体活 動時間が長かった。これらの結果は中学 1 年生以外で有 意差が認められた。

抑うつ症状に対する予測因子 予測因子と新たに抑うつ 症状を呈した児童生徒の関係を明らかにするためにロジ スティック回帰分析を行なった。男子において，単変量 ロジスティック回帰分析の結果，身体活動時間が短いこ とに対して身体活動時間が長いこと（OR: 0.31, 95\%CI: 0.11-0.75), 平日の就寝時刻が早いことに対して就寝時 刻が遅いこと (OR: 2.22, 95\%CI: 1.13-4.62)，ボディイ メージが今のままがよいに対して少しだけやせたいこ と（OR: 2.08,95\%CI: 1.02-4.29）が新たに抑うつ症状を 呈することに影響していた。次に抑うつ症状に対する 予測因子として調查した全ての因子，ベースラインの DSRS-C得点抒よび学年で調整を行なった多変量ロジス ティック回帰分析の結果，身体活動時間が長いことが新 たに抑うつ症状を呈することのリスクを減少させていた

Table 2. Median of DSRS-C score at 2008 (baseline) between group of not having depressive symptoms and having depressive symptoms at 2009 (follow-up) by gender and grade

\begin{tabular}{|c|c|c|c|c|c|c|c|c|c|}
\hline & \multirow[b]{2}{*}{ School Grade } & \multicolumn{3}{|c|}{$\begin{array}{l}\text { Depressive Symptoms (2009) } \\
\text { Not case on DSRS-C }\end{array}$} & \multicolumn{3}{|c|}{$\begin{array}{c}\text { Depressive Symptoms (2009) } \\
\text { Case on DSRS-C }\end{array}$} & \multirow[b]{2}{*}{$P$ value } & \multirow[b]{2}{*}{ Incidence (\%) } \\
\hline & & N & Median & Score Range & $N$ & Median & Score Range & & \\
\hline \multirow{5}{*}{ Boys } & 4 & 99 & 7 & $0 \sim 15$ & 6 & 7.5 & $1 \sim 12$ & 0.87 & 5.7 \\
\hline & 5 & 166 & 7 & $0 \sim 15$ & 10 & 10.5 & $0 \sim 15$ & 0.09 & 5.7 \\
\hline & 6 & 122 & 6 & $0 \sim 15$ & 6 & 9.5 & $5 \sim 12$ & 0.14 & 4.7 \\
\hline & 7 & 122 & 5.5 & $0 \sim 14$ & 8 & 10 & $6 \sim 15$ & 0.003 & 6.2 \\
\hline & 8 & 128 & 6.5 & $0 \sim 15$ & 11 & 11 & $6 \sim 15$ & 0.002 & 7.9 \\
\hline \multirow{5}{*}{ Girls } & 4 & 100 & 7 & $0 \sim 14$ & 10 & 10.5 & $4 \sim 14$ & 0.04 & 9.1 \\
\hline & 5 & 135 & 7 & $0 \sim 15$ & 4 & 11 & $7 \sim 14$ & 0.07 & 2.9 \\
\hline & 6 & 113 & 7 & $0 \sim 15$ & 13 & 11 & $2 \sim 15$ & 0.008 & 10.3 \\
\hline & 7 & 112 & 7 & $1 \sim 15$ & 16 & 10.5 & $0 \sim 15$ & 0.008 & 12.5 \\
\hline & 8 & 113 & 7 & $1 \sim 15$ & 25 & 11 & $2 \sim 14$ & $<0.001$ & 18.1 \\
\hline
\end{tabular}

DSRS-C: Birleson depressive self-rating scale for children 
Table 3. Weekly hours of physical activity at 2008 (baseline) by gender and grade

\begin{tabular}{cccccc} 
& \multicolumn{2}{c}{ Boys } & \multicolumn{2}{c}{ Girls } & \\
\cline { 2 - 5 } School Grade & $\mathrm{N}$ & $\mathrm{M} \pm \mathrm{SD}(\mathrm{h} /$ week $)$ & $\mathrm{N}$ & $\mathrm{M} \pm \mathrm{SD}(\mathrm{h} /$ week $)$ & P value \\
\hline 4 & 159 & $6.2 \pm 10.1$ & 138 & $3.2 \pm 3.9$ & $<.0001$ \\
5 & 206 & $8.5 \pm 7.4$ & 158 & $5.1 \pm 6.8$ & $<.0001$ \\
6 & 148 & $11.0 \pm 11.5$ & 155 & $6.8 \pm 10.3$ & $<.0001$ \\
7 & 168 & $12.9 \pm 8.3$ & 158 & $11.4 \pm 8.1$ & 0.11 \\
8 & 173 & $15.5 \pm 9.1$ & 185 & $11.6 \pm 8.5$ & $<.0001$ \\
\hline
\end{tabular}

Mean \pm Standard Deviation

Table 4. Crude and adjusted odds ratios (OR) and 95\% confidence interval (CI) of depressive symptoms at 1-year follow-up for the independent variable at baseline in boys.

The OR and 95\%CI were determined using logistic multivariable regression analysis.

\begin{tabular}{|c|c|c|c|c|c|}
\hline \multirow[b]{2}{*}{ Baseline } & \multicolumn{3}{|c|}{ Depressive symptoms (follow-up) } & \multirow{2}{*}{$\begin{array}{c}\text { Crude } \\
\text { OR }(95 \% \mathrm{CI})\end{array}$} & \multirow{2}{*}{$\begin{array}{l}\text { Adjusted }{ }^{※} \\
\text { OR }(95 \% \mathrm{CI})\end{array}$} \\
\hline & $\mathrm{N}$ & Case ( & Incidence (\%) & & \\
\hline \multicolumn{6}{|l|}{-Physical activity } \\
\hline Low & 228 & 18 & 7.9 & 1.00 & 1.00 \\
\hline Middle & 218 & 17 & 7.8 & $0.99(0.49-1.98)$ & $1.10(0.51-2.35)$ \\
\hline High & 232 & 6 & 2.6 & $0.31(0.11-0.75)$ & $0.37(0.12-0.95)$ \\
\hline \multicolumn{6}{|l|}{-Breakfast consumption } \\
\hline "I occasionally skip breakfast" & 80 & 4 & 5.0 & $0.85(0.25-2.19)$ & $0.53(0.15-1.48)$ \\
\hline "I don't skip breakfast" & 607 & 37 & 6.1 & 1.00 & 1.00 \\
\hline \multicolumn{6}{|l|}{-Bed time (weekday) } \\
\hline Early & 320 & 12 & 3.8 & 1.00 & 1.00 \\
\hline Late & 345 & 27 & 7.8 & $2.22(1.13-4.62)$ & $2.44(1.17-5.39)$ \\
\hline \multicolumn{6}{|l|}{ - Sense of awaking } \\
\hline good & 146 & 8 & 5.5 & 1.00 & 1.00 \\
\hline a little sleepy & 430 & 21 & 4.9 & $0.87(0.39-2.14)$ & $0.38(0.15-1.02)$ \\
\hline very sleepy & 108 & 12 & 11.1 & $2.18(0.87-5.75)$ & $0.87(0.30-2.54)$ \\
\hline \multicolumn{6}{|l|}{ - Video game (h/day) } \\
\hline 0 hour & 72 & 5 & 6.9 & 1.00 & 1.00 \\
\hline 30 minutes $\sim 1.5$ hours & 474 & 26 & 5.5 & $0.77(0.31-2.35)$ & $0.57(0.21-1.82)$ \\
\hline more than 2 hours & 138 & 10 & 7.3 & $1.06(0.36-3.51)$ & $0.56(0.17-2.05)$ \\
\hline \multicolumn{6}{|l|}{$\cdot$ BMI } \\
\hline Thin & 99 & 4 & 4.0 & $0.59(0.17-1.52)$ & $0.75(0.19-2.31)$ \\
\hline Normal & 481 & 32 & 6.7 & 1.00 & 1.00 \\
\hline Overweight & 103 & 4 & 3.9 & $0.56(0.16-1.44)$ & $0.40(0.11-1.20)$ \\
\hline \multicolumn{6}{|l|}{ - Body image } \\
\hline I'd like to get thin considerably & 68 & 4 & 5.9 & $1.27(0.35-3.64)$ & $0.90(0.22-3.04)$ \\
\hline I'd like to get thin a little & 194 & 18 & 9.3 & $2.08(1.02-4.29)$ & $1.63(0.72-3.70)$ \\
\hline I'd like to maintain the present body & 317 & 15 & 4.7 & 1.00 & 1.00 \\
\hline I'd like to get fat a little & 105 & 4 & 3.8 & $0.80(0.22-2.26)$ & $0.89(0.23-2.76)$ \\
\hline I'd like to get fat considerably & 2 & 0 & 0.0 & - & - \\
\hline
\end{tabular}

OR: odds ratio, CI: confidence interval

※: Adjusted for all presented variables, grade and DSRS-C score at baseline 
(OR: 0.37, 95\%CI: 0.12-0.95)。また，平日の就寝時刻が 遅いこと（OR: 2.44,95\%CI: 1.17-5.39）が新たに抑うつ 症状を呈しやすいことに影響していた（Table 4).さら に身体活動時間が長くなることによって新たに抑うつ症 状を呈することに傾向性を有しているのかを明らかに するためにCochran-Armitageの傾向検定を行なった結 果，有意な傾向を示した（P值：0.008）.

女子においては, 単変量ロジスティック回帰分析の結 果, 朝食欠食がないに対して朝食欠食があること（OR： 2.30, 95\%CI: 1.04-4.67), すっきり目覚めるに対して眠 くてなかなか起きられないこと（OR: 3.89, 95\%CI: 1.709.74)，体型が今のままがよいに対してかなりやせたいこ
と（OR: 3.71, 95\%CI: 1.80-7.68）が新たに抑うつ症状を 呈することに影響していた。次に抑うつ症状に対する予 測因子として本研究で調査した全ての因子, ベースライ ンのDSRS $-\mathrm{C}$ 得点および学年で調整を行なった多変量ロ ジスティック回帰分析の結果, かなりやせたいこと（OR： 2.47, 95\%CI：1.01-6.07）のみが，新たに抑うつ症状を呈 することのリスクとなっていた。

\section{考察}

小学校 4 年生から中学校 2 年生までの児童生徒を対象 とした 1 年間の追跡調査の結果，男子は身体活動量の違 いが新たに抑うつ症状を呈することに影響していた。し

Table 5. Crude and adjusted odds ratios (OR) and 95\% confidence interval (CI) of depressive symptoms at 1-year follow-up for the independent variable at baseline in girls.

The OR and 95\%CI were determined using logistic multivariable regression analysis.

\begin{tabular}{|c|c|c|c|c|c|}
\hline \multirow[b]{2}{*}{ Baseline } & \multicolumn{3}{|c|}{ Depressive symptoms (follow-up) } & \multirow{2}{*}{$\begin{array}{c}\text { Crude } \\
\text { OR }(95 \% \mathrm{CI})\end{array}$} & \multirow{2}{*}{$\begin{array}{l}\text { Adjusted }{ }^{*} \\
\text { OR }(95 \% \mathrm{CI})\end{array}$} \\
\hline & $\mathrm{N}$ & Case $(\mathrm{N})$ & Incidence (\%) & & \\
\hline \multicolumn{6}{|l|}{-Physical activity } \\
\hline Low & 233 & 26 & 11.2 & 1.00 & 1.00 \\
\hline Middle & 196 & 19 & 9.7 & $0.97(0.53-1.59)$ & $0.80(0.39-1.63)$ \\
\hline High & 212 & 23 & 10.9 & $0.97(0.53-1.76)$ & $1.05(0.54-2.04)$ \\
\hline \multicolumn{6}{|l|}{-Breakfast consumption } \\
\hline "I occasionally skip breakfast" & 50 & 10 & 20.0 & $2.30(1.04-4.67)$ & $1.45(0.60-3.23)$ \\
\hline "I don't skip breakfast" & 593 & 58 & 9.8 & 1.00 & 1.00 \\
\hline \multicolumn{6}{|l|}{-Bed time (weekday) } \\
\hline Early & 267 & 24 & 9.0 & 1.00 & 1.00 \\
\hline Late & 358 & 42 & 11.7 & $1.35(0.80-2.33)$ & $0.86(0.48-1.56)$ \\
\hline \multicolumn{6}{|l|}{ - Sense of awaking } \\
\hline good & 125 & 8 & 6.4 & 1.00 & 1.00 \\
\hline a little sleepy & 414 & 39 & 9.4 & $1.52(0.73-3.59)$ & $1.11(0.47-2.95)$ \\
\hline very sleepy & 102 & 21 & 20.6 & $3.89(1.70-9.74)$ & $2.26(0.84-6.62)$ \\
\hline \multicolumn{6}{|l|}{ - Video game (h/day) } \\
\hline 0 hour & 102 & 12 & 11.8 & 1.00 & 1.00 \\
\hline 30 minutes $\sim 1.5$ hours & 469 & 49 & 10.5 & $0.88(0.46-1.79)$ & $0.66(0.32-1.44)$ \\
\hline more than 2 hours & 68 & 7 & 10.3 & $0.88(0.31-2.30)$ & $0.41(0.12-1.24)$ \\
\hline \multicolumn{6}{|l|}{-BMI } \\
\hline Thin & 88 & 10 & 11.4 & $1.19(0.55-2.37)$ & $1.32(0.50-3.22)$ \\
\hline Normal & 479 & 47 & 9.8 & 1.00 & 1.00 \\
\hline Overweight & 71 & 10 & 14.1 & $1.50(0.69-3.02)$ & $1.04(0.42-2.35)$ \\
\hline \multicolumn{6}{|l|}{-Body image } \\
\hline I'd like to get thin considerably & 80 & 18 & 22.5 & $3.71(1.80-7.68)$ & $2.47(1.01-6.07)$ \\
\hline I'd like to get thin a little & 290 & 28 & 9.7 & $1.36(0.73-2.60)$ & $0.82(0.39-1.73)$ \\
\hline I'd like to maintain the present body & 233 & 17 & 7.3 & 1.00 & 1.00 \\
\hline I'd like to get fat a little & 36 & 4 & 11.1 & $1.65(0.45-4.80)$ & $0.98(0.20-3.54)$ \\
\hline I'd like to get fat considerably & 2 & 0 & 0.0 & - & - \\
\hline
\end{tabular}

OR: odds ratio, CI: confidence interval

※: Adjusted for all presented variables, grade and DSRS-C score at baseline 
かし，女子は身体活動量の違いが新たに抑うつ症状を呈 することに関連していなかった。

本研究は全国の代表サンプルではないため外的妥当性 に限界がある。しかし，生活習慣や体型については，一 般に指摘されている日本人児童の特性に類似していた。 例えば，独立変数である身体活動量は，中学生で 1 週間 の総運動時間が 60 分未満である男子 $9.3 \%$.女子 $31.1 \%{ }^{27)}$ に対して, 本研究では全く身体活動を行わない男子 $3.4 \%$. 女子 $13.6 \%$ あった。ささらに調整変数では，朝食を毎日 食べる小学 5 年生抒よび中学 2 年生の男子 $88.2 \%$.女 子 $90.5 \%{ }^{28)}$ に対して, 本研究では朝食を毎日食べる男子 88.4\%・女子 $92.2 \%$ あったた. 1 日あたり 2 時間以上テ レビゲームを行なう小中学生男子 $19.0 \% \cdot 女 子 7.2 \%$. 対して, 本研究では 1 日あたり 2 時間以上テレビゲー ム, パソコン, 携帯電話で遊ぶ男子 $20.2 \%$.女子 $10.6 \%$ で あった。平日の就寝時刻が22時前の小学生 $56.6 \% \cdot 23$ 時 前の中学生 $37.0 \%{ }^{29)}$ に対して, 本研究では平日の就寝時 刻が 22 時前の小学生 $46.3 \% \cdot 23$ 時前の中学生 $42.7 \%$ であっ た。過体重である小学 4 年生から中学 2 年生までの男子 9.1 11.1\% • 女子 $7.5 \sim 8.8 \%{ }^{30)}$ に対して, 本研究では過体 重である男子15.1\%・女子11.1\%であった。やや願望のあ る男子小学生 $24.0 \sim 28.3 \%$, 男子中学生 $30.0 \%$, 女子小学 生31.2 34.3\%, 女子中学生 $78.0 \%{ }^{20)}$ に対して, 本研究で

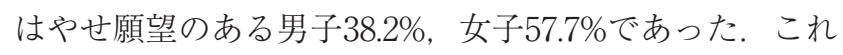
らのことから, 選択バイアスによる結果への影響は限定 的であると考える，また，新たに抑うつ症状を呈する。 呈さない 2 群に分けてベースラインのDSRS-C得点の検 定を行なった（Table 2)。その結果，新たに抑うつ症状 を呈する群の方が新たに抑うつ症状を呈さない群よりも DSRS-C得点が有意に高かった。したがって、ベースラ インのDSRS-C得点の高さが新たな抑うつ発症の前兆を 呈している可能性があり, その状況が身体活動量を低く させている影響を除外するため, 多変量ロジスティック 回帰分析ではベースラインのDSRS-C得点で調整した.

身体活動がメンタルヘルスに影響を及ぼすことについ て, 男女間の相違を明らかにしている研究はわずかであ る. Sagatun et al. ${ }^{31)}$ によれば, 2489人を対象に15歳から 16 歳時点の身体活動時間と 3 年後のメンタルヘルスの関 連を検討し，男子には影響が認められたが，女子には影 響が認められないことが示されている。また，12歳から 18歳を対象にしたTaliaferro et al. ${ }^{32}$ の研究によれば, 男 子では，身体活動頻度が高いことは自殺企図が低い関倸 にあることを示したが，女子には認められないことが報 告されている。 これらの結果は我々の結果と一致してい る.

男子中学生を対象に身体活動と抑うつ症状の関係を示

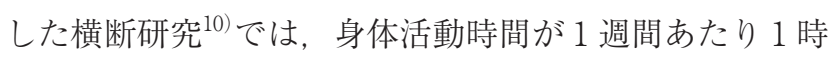
間未満に対して $1 \sim 7$ 時間， 8〜14時間，15時間以上
で抑うつ症状を有するオッズ比が，それぞれ0.74， 0.54 , 0.56であった。 1 週間あたりの身体活動時間が長いこと がより抑うつ症状を呈しにくい関連性がうかがえる。ま た，本研究に打いてもCochran-Armitageの傾向検定が 有意であったことから, 男子は発達段階を考慮した中で (Table 1)，可能な限り身体活動を行なうことが望まし いと考える。

男女間の相違は, 余暇時間の過ごし方や身体活動を行 なうことによるサポート享受の認識にも表れている，余 暇時間の過ごし方は男子が身体活動, 女子が芸術的な活 動を行なう傾向にある ${ }^{33}$. そして, 身体活動を行なうこ とにより男子は女子よりも家族や友人からサポートを享 受していることを認識している34)，スポーツ活動に参加 することは自尊感情やソーシャルサポートを介して抑う

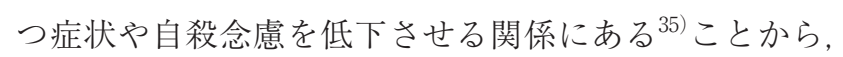
スポーツ活動への参加やサポート享受の認識の違いが男 女間での結果の相違として反映したことが考えられる.

本研究では, 身体活動以外にも抑うつ症状に影響を及 ぼす要因を示した，男子については，平日の就寝時刻が 遅いことは新たに抑うつ症状を呈することに影響してい た. Pasch et al. ${ }^{12)}$ やKaneita et $\mathrm{al}^{36)}$ によれば中学生や高 校生を対象に睡眠時間や睡眠の質など睡眠習慣の悪さが メンタルヘルスの悪化につながること，平日の睡眠時間 が長いことは抑うつ症状が低下する関係にあることを示 している，女子については，実際の体型（BMI）は新た に抑うつ症状を呈することに影響していなかったが，ボ ディイメージ，すなわち，自分の体型に対する不満足度 は新たに抑うつ症状を呈することに影響していた。多く の先行研究 ${ }^{15,37-40)}$ では, 女子は実際の体型よりも自分の 体型に不満を抱いていると抑うつ症状を呈しやすいこと を明らかにしている，10代の女子は体型不満を解決する ために運動よりも食事制限によって体重をコントロール する傾向にあり，食事制限を介して抑うつ症状を呈する ことが考えられる ${ }^{41-43)}$

本研究の限界として, 質問紙の信頼性および妥当性が 十分に担保できていないことが挙げられ，さらに身体活 動量を 1 週間の合計時間のみで評価していることも限界 と考えられる。また, 質問の読み取り方により, 身体活 動の内容が部活動やスポーツクラブなどに限定され, 学 校での休み時間や放課後の外遊びの運動を反映していな い可能性もあり, 質問方法の検討や質問項目の信頼性お よび妥当性の検証を行なうことも必要である，もう一つ の限界として, 身体活動や抑うつ症状に関連する社会経 済状況など多くの因子が未検討であるため, これらの因 子が交絡となり身体活動と抑うつ症状との関係を歪めて いる可能性がある。特に小中学生期の女子は, 第二次性 徵や友人関係が心身ともに大きな影響を及ぼしており, これらの因子を考慮にいれた研究デザインが必要と思わ 
れる，最後に小学生と中学生では新たに抑うつ症状を呈 する発生率が異なる（Table 2) ことから，学年による 影響を排除するために層別化することが望ましい，しか しサンプルサイズの限界から層別化することができな かったことも限界の一つである。一方, 本研究の強みは, 我が国の児童生徒を対象に身体活動と抑うつ症状の関係 について初めて縦断的に検討したことである.さらに, コミュニティベースで行なわれ, 参加同意率も追跡率も 高かったことである.

\section{結 論}

我が国の児童生徒において，男子は身体活動が新たに 抑うつ症状を呈することのリスクを減少させていたこと が示唆された。一方，女子は身体活動が新たに抑うつ症 状を呈することに影響せず，実際の体型よりも自分の体 型に不満を抱いていることが新たに抑うつ症状を呈する ことに影響する可能性が示唆された。 今後, 身体活動と 抑うつ症状に関係する交絡因子を整理し, 知見を蓄積す ることが望まれる。

\section{文献}

1）中江悟司。アクティブ・チャイルド $60 \mathrm{~min}$, 初版, 現 存の子どもに見られる身体活動不足, 座位中心生活に よる影響，東京：サンライフ企画，128-129，2010.

2) Sun Y, Sekine M, Kagamimori S. Lifestyle and overweight among japanese adolescents: the toyama birth cohort study. J Epidemiol 19: 303-310, 2009.

3) Kempf K, Rathmann W, Herder C. Impaired glucose regulation and type 2 diabetes in children and adolescents. Diabetes Metab Res Rev 24: 427-437, 2008.

4) Riemenschneider M, Nocon M, Willich S. Prevalence of modifiable cardiovascular risk factors in german adolescents. Eur J Cardiovasc Prev Rehabil 17: 204-210, 2010.

5) Kantomaa M, Tammelin T, Ebeling H, Taanila A. Emotional and behavioral problems in physical activity in youth. Med Sci Sports Exerc 40: 1749-1756, 2008.

6) Teychenne M, Ball K, Salmon J. Physical activity and likelihood of depression in adult: A review. Prev Med 46: 397-411, 2008.

7) Jonsdottir I, Rodjer L, Hadzibajramovic E, Borjesson M, Ahlborg G Jr. A prospective study of leisure-time physical activity and mental health in swedish health care worker and social insurance officers. Prev Med 51: 373-377, 2010.

8) Goodwin R. Association between physical activity and mental disorders among adult in the united states. Prev Med 36: 698-703, 2003.

9) Motl R, Birnbaum A, Kubik M, Dishman R. Naturally occurring changes in physical activity are inversely related to depressive symptoms during early adolescence. Phychosoma Med 66: 336-342, 2004.

10) Hong $\mathrm{X}$, Li J, Xu F, Tse L, Liang Y, Wang Z, Yu I,
Griffiths S. Physical activity inversely associated with the presence of depression among urban adolescents in regional china. BMC Pub Health 148, 2009.

11）傳田健三，子どものうつ病，公衆衛生 72, 21-24, 2008.

12) Pasch K, Lasaka M, Lytle L, Moe S. Adolescent sleep, risk behaviors, and depressive symptoms: are they linked? Am J Health Behav 34: 237-248, 2010.

13) Primack B, Swanier B, Anna M, Land S, Michael J. Association between media use in adolescence and depression in young adulthood. Arch Gen Psychiatry 66: 181-188, 2009.

14) Xie B, Unger J, Gallaher P, Johnson C, Wu Q, Chou C. Overweight, body image, and depression in asian and hispanic adolescents. Am J Health Behav 34: 476-488, 2010.

15) Stice E, Bearman S. Body image and eating disturbances prospectively predict increases in depressive symptoms in adolescent girls: a growth curve analysis. Dev Psychol 37: 597-607, 2001.

16) Lemstra M, Neudorf C, D'Arcy C, Kunst A, Warren L, Bennett N. A systematic review of depressed mood and anxiety by ses in youth aged 10-15 years. Can $J$ Pub Health 99: 125-129, 2008.

17) Bouma E, Ormel J, Verhulst F, Oldehinkel A. Stressful life events and depressive problems in early adolescent boys and girls: the influence of parental depression, temperament and family environment. J Affect Disorders 105: 185-193, 2008.

18）松平宗之, 高井和夫，子どもの運動意欲を支える心理 社会的要因, 文教大学教育学部紀要 44, 129-142, 2010.

19）三上聡子, 三村寛一, 肥満児童の身体活動とエネルギー バランスに関する運動生理学的研究, 体力科学 42 , 720, 1993.

20）文部科学省, 『平成16年度児童生徒の健康状態サーベ イランス事業報告書』, 60-67, 2006.

21) Birleson P, Hudson I, Buchnan DG, Wolff S. Clinical evaluation of a self-rating scale for depressive disorder in children (depression self-rating scale). $J$ Child Psychol Psychi and Allied Disci 28, 43-60, 1987.

22）村田豊久, 清水亜紀, 森陽二郎, 大島祥子, 学校に打 ける子どものうつ病 - Birlesonの小児期うつ病スケー ルからの検討 一, 最新精神医学 1, 131-138, 1996.

23）傳田健三，子供のうつ病，母子保健情報 55，69-72, 2007.

24）高倉実，小林稔，宮城政也，小橋川久光，加藤種 一, 児童に扔ける身体活動質問項目の信頼性と妥当 性: WHO Health Behaviour in School-aged Children Survey日本語版の場合, 琉球大学教育学部紀要 69 , 199-205, 2006.

25) Cole TJ, Flegal KM, Nicholls D, Jackson AA. Body mass index cut off to define thinness in children and adolescents: international survey. BMJ 335, 194, 2007.

26) Cole TJ, Bellizzi MC, Flegal KM, Dietz WH. Establishing a standard definition for child overweight and obesity worldwide: international survey. BMJ 320, 1240, 
2000.

27）文部科学省，『平成22年度全国体力 · 運動能力 - 運動 習慣等調査結果の概要』, 1-9, 2010.

28）文部科学省，『平成20年度全国体力 · 運動能力 - 運動 習慣等調査結果の概要』, 39-72, 2009.

29）ベネッセ教育研究開発センター, 『第1回子ども生活実 態基本調査報告書』，18-40，2005.

30）文部科学省, 『平成 22 年度学校保健統計調査結果の概 要』, 6-22, 2010.

31) Sagatun A, Sogaard A, Bjertness E, Selmer R, Heyerdahl S. The association between weekly hours of physical activity and mental health: A three-year follow-up study of 15-16-year-old students in the city of Oslo, Norway. BMC Pub Health 155, 2007.

32) Taliaferro L, Rienzo B, Miller D, Pigg M, Dodd V. High school youth and suicide risk: exploring protection afforded through physical activity and sport participation. J School Health 78: 545-553, 2008.

33) Mota J, Santos M, Ribeiro J. Differences in leisuretime activities according to level of physical activity in adolescents. J Phys Act Health 5: 286-293, 2008.

34) Cardon G, Philippaerts R, Lefevre J, Matton L, Wijndaele K, Balduck A, Bourdeaudhuij I. Physical activity levels in 10 to 11 year olds: clustering of psychosocial correlates. Pub Health Nutrition 8: 896-903, 2005.

35) Babiss LA, Gangwisch JE. Sports participation as a protective factor against depression and suicidal ideation in adolescents as mediated by self-esteem and social support. J Devel \& Behav Pediat 30: 367-384, 2009.
36) Kaneuta Y, Yokoyama E, Harano S, Tamaki T, Suzuki H, Munezawa T, Nakajima H, Asai T, Ohida T. Associations between sleep disturbance and mental health status: a longitudinal study of japanese junior high school students. Sleep Med 10: 780-786, 2009.

37) Ali MM, Fang H, Rizzo JA. Body weight, self-perception and mental health outcomes among adolescents. $J$ Ment Health Policy Econ 13: 53-63, 2010.

38) Bearman S, Stice E. Testing a gender additive model: the role of body image in adolescent depression. $J$ Abnorm Child Psychol 36: 1251-1263, 2008.

39) Mamun A, Cramb S, McDermott B, O'Callaghan M, Najman J, Williams G. Adolescents' perceived weight associated with depression in young adulthood: a longitudinal study. Obesity 15: 3097-3105, 2007.

40) Ozmen D, Ozmen E, Ergin D, Cetinkaya A, Sen N, Dundar P, Taskin E. The association of self-esteem, depression and body satisfaction with obesity among turkish adolescents. BMC Pub Health 7: 2007.

41) Lynch W, Heil D, Wagner E, Havens M. Body dissatisfaction mediates the association between body mass index and risky weight control behaviors among white and native american adolescent girls. Appetite 51: 210-213, 2008.

42) Liechty J. Boby image distortion and three types of weight loss behaviors among nonoverweight girls in the united states. J Adoles Health 47: 176-182, 2010.

43) Needham B, Crosnoe R. Overweight status and depressive symptoms during adolescence. $J$ Adoles Health 36 : 48-55, 2005.

Appendix

The contents of a question and alternative of an independent variables.

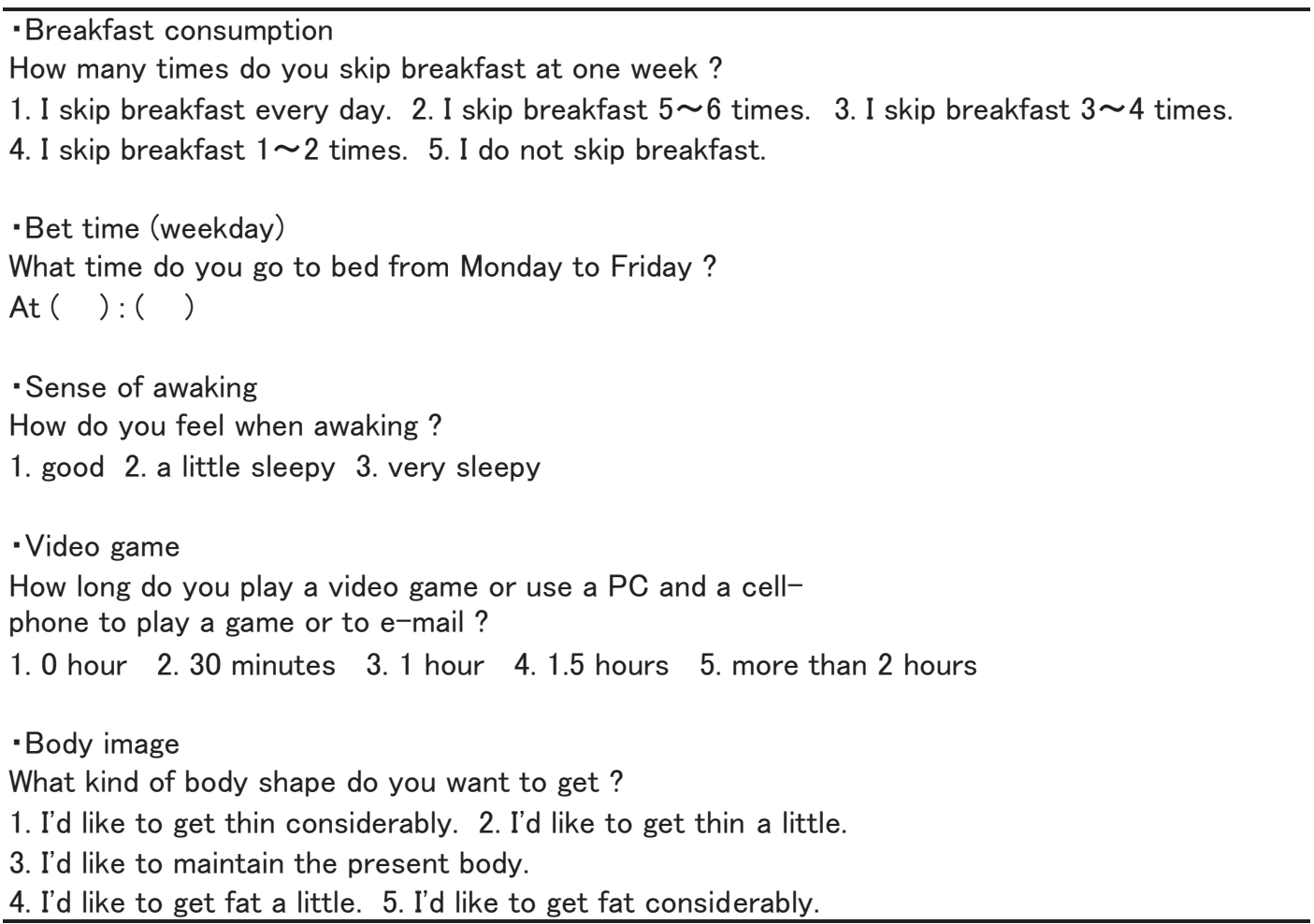

